\title{
Lethality of gInD null mutations in Azotobacter vinelandii is suppressible by prevention of glutamine synthetase adenylylation
}

\author{
Rita Colnaghi, $†$ Paul Rudnick, Luhong He, Andrew Green, $\ddagger$ Dalai Yan, $\mathbb{S}$ \\ Ethan Larson and Christina Kennedy
}

Department of Plant Pathology, College of Agriculture, PO Box 210036, The University of Arizona, Tucson, AZ 85721, USA

\author{
Author for correspondence: Christina Kennedy. Tel: +1 5206219835 . Fax: +1 5206219290 \\ e-mail: ckennedy@u.arizona.edu
}

Keywords: nitrogen fixation, nitrogen assimilation, $\mathrm{GlnD}, \mathrm{NtrC}$, nif gene regulation

\section{INTRODUCTION}

The $g \ln D$ gene product is thought to be a component of the Azotobacter vinelandii fixed $\mathrm{N}$ signal transduction pathway that regulates nif gene expression. Certain Tn5 $\mathrm{Nif}^{-}$regulatory mutations were located in a gene, originally named $n f r X$, that was shown by subsequent sequencing to encode a protein highly similar to the glnD gene product of Escherichia coli (Santero et al., 1988; Contreras et al., 1991). The only discernible phenotype of $n f r X$ mutant MV17 was $\mathrm{Nif}^{-}$, which could be corrected by introducing either a nifL: : kan mutation

\footnotetext{
† Present address: School of Biological Sciences, Sussex University, Falmer, Brighton BN1 9QG, UK.

$\ddagger$ Present address: MRC, Cell Mutation Unit, Sussex University, Falmer, Brighton BN1 9RR, UK.

SPresent address: Eli Lilly and Co., Indianapolis, IN 46275, USA.

Abbreviations: ATase, adenylyltransferase; GS, glutamine synthetase.
}

or the E. coli glnD gene on a wide host range plasmid (Contreras et al., 1991).

In enteric bacteria, GlnD and the small trimeric PII proteins, encoded by $g \ln B$, and $G \ln K$, a PII paralogue, constitute a cellular $\mathrm{N}$ sensor. Biochemical experiments using wild-type cell extracts, and also in vitro systems, to examine the activities of purified proteins, have shown that the activity states of these proteins are dependent on small effector molecules and influence a cascade of events leading to the activation or inactivation of proteins involved in nitrogen metabolism (for reviews, see Merrick \& Edwards, 1995; Reitzer, 1996). GlnD contains both uridylyltransferase and uridylylremoving activities that are regulated largely by glutamine (Jiang et al., 1998). In wild-type cells grown in Nlimiting conditions, GlnD reversibly uridylylates PII (Son \& Rhee, 1987) and GlnK (van Heeswijk et al., 1995). PII-UMP or GlnK-UMP increase the rate of 
Table 1. Strains and plasmids

\begin{tabular}{|c|c|c|}
\hline Strain/plasmid & Characteristics & Source/reference \\
\hline \multicolumn{3}{|l|}{ A. vinelandii } \\
\hline MV17 & $n f r X 16(g \ln D):: \operatorname{Tn} 5\left(\mathrm{Nif}^{-}\right)$ & Santero et al. (1988) \\
\hline MV71 & $g \ln D 1:: \Omega g \ln -71\left(\mathrm{Nif}^{-}\right)$ & This work \\
\hline MV72 & $g \ln -71\left(\mathrm{Nif}^{+}\right)$ & This work \\
\hline MV73 & $g \ln D 1:: \Omega g \ln -71$ nifL1::KIXX $\left(\mathrm{Nif}^{+}\right)$ & This work \\
\hline MV74 & $g \ln A 8(\mathrm{GSY} 407 \mathrm{~F})\left(\mathrm{Nif}^{+}\right)$ & This work \\
\hline MV75 & $g \ln D 1:: \Omega g \ln A 8(\mathrm{GSY} 407 \mathrm{~F})\left(\mathrm{Nif}^{-}\right)$ & This work \\
\hline UW136 & rif1 $\left(\mathrm{Nif}^{+}\right)$ & $\begin{array}{l}\text { Bishop \& Brill } \\
\text { (1977) }\end{array}$ \\
\hline \multicolumn{3}{|l|}{ E. coli } \\
\hline DH5 $\alpha$ & $\begin{array}{l}\text { supE44 } \Delta \text { lac } \mathrm{U} 69(\phi 80 \text { lacZ } \Delta \mathrm{M} 15) \text { hsdR17 recA1 } \\
\text { gyrA96 thi1 relA1 }\end{array}$ & $\begin{array}{l}\text { Sambrook et al. } \\
\text { (1989) }\end{array}$ \\
\hline $71 / / 18$ & $\begin{array}{l}\text { supE thi } \Delta(\text { lac-proAB }) \mathrm{F}^{\prime}\left[\text { proAB }^{+} \text {lacl }{ }^{\alpha} \text { lac }\right. \\
\Delta \mathrm{M} 15]\end{array}$ & $\begin{array}{l}\text { Sambrook et al. } \\
\text { (1989) }\end{array}$ \\
\hline \multicolumn{3}{|l|}{ Plasmids } \\
\hline pAG401 & $\begin{array}{l}\text { Pst } \mathrm{I}-E c o \mathrm{RI} \text { fragment from pAT512 containing the } \\
\operatorname{gln} \text { A gene cloned in pTZ19R }\end{array}$ & This work \\
\hline pAG444 & $\begin{array}{l}\text { PstI-EcoRI fragment cloned into pTZ19R } \\
\text { containing the mutated } g \ln A \text { gene }\end{array}$ & This work \\
\hline pAT512 & $\begin{array}{l}12 \cdot 5 \mathrm{~kb} \text { HindIII-ClaI fragment from cosmid pVL51 } \\
\text { containing A. vinelandii glnA gene }\end{array}$ & $\begin{array}{l}\text { Toukdarian \& } \\
\text { Kennedy (1986) }\end{array}$ \\
\hline pBluscript & Cloning and sequencing vector $\left(A m p^{r}\right)$ & Stratagene \\
\hline pDK805 & E. coli glnE cloned in pUC18 & $\begin{array}{l}\text { van Heeswijk et al. } \\
\text { (1993) }\end{array}$ \\
\hline pLAFR3 & $22 \mathrm{~kb}$ Cosmid $\left(\right.$ Tet $\left.^{\mathrm{r}}\right)$ & Peet et al. (1986) \\
\hline pPR 803 & E. coli glnE cloned in pLAFR3 & This work \\
\hline pPH45 & Plasmid containing $\Omega\left(\operatorname{Str}^{r} \operatorname{Spc}^{r}\right)$ cassette & $\begin{array}{l}\text { Prentki and Krisch } \\
\text { (1984) }\end{array}$ \\
\hline pRCS1 & $\begin{array}{l}3 \cdot 3 \mathrm{~kb} \text { Bam HI-KpnI fragment from pSS166 cloned } \\
\text { in pBluescript }\end{array}$ & This work \\
\hline $\operatorname{pRCS} 1:: \Omega$ & $\begin{array}{l}\Omega \text { cassette inserted between the two Pst I sites in } \\
g \ln D \text { in pRCS1 }\end{array}$ & This work \\
\hline pSS166 & $4.7 \mathrm{~kb} K p n \mathrm{I}$ fragment containing $g \ln D$ in $\mathrm{pTZ} 18$ & Santero et al. (1988) \\
\hline pSS1663 & $\begin{array}{l}\text { KIXX cassette inserted between BamHI and BglII } \\
\text { sites in pSS166 }(g \ln D 2:: \text { KIXX) }\end{array}$ & This work \\
\hline pSSK & $\begin{array}{l}\text { KIXX cassette inserted between the two SalI sites } \\
\text { in pSS166 }(g \ln D 3:: \text { KIXX) }\end{array}$ & This work \\
\hline pTU13 & $\begin{array}{l}\text { KIXX cassette inserted in the } B g l \mathrm{II} \text { site } \\
\text { downstream of } g \ln D\end{array}$ & This work \\
\hline $\mathrm{pTZ18R} / \mathrm{pTZ19R}$ & Cloning and sequencing vectors $\left(A m p^{r}\right)$ & Pharmacia \\
\hline pUC4::KIXX & Plasmid containing KIXX $\left(\operatorname{Kan}^{r}\right)$ cassette & Pharmacia \\
\hline
\end{tabular}

deadenylylation (activation) of glutamine synthetase (GS) by stimulation of the adenylyl-removing activity of adenylyltransferase (ATase), the product of the $g \ln E$ gene (van Heeswijk et al., 1995; Edwards \& Merrick, 1995; Jaggi et al., 1997). In cells transferred to N-rich medium, GlnD deuridylylates PII and GlnK (van Heeswijk et al., 1996). PII stimulates the ATase activity of GlnE (Jaggi et al., 1997) and also the phosphatase activity of NtrB (Kamberov et al., 1995; Jiang \& Ninfa, 1999), leading to the dephosphorylation and inactivation of the transcriptional activator, NtrC. Because the $g \ln K$ gene in enteric bacteria requires phosphorylated $\mathrm{NtrC}$ (NtrC-P) for expression, GlnK synthesis does not occur in E. coli cultures grown with ammonium (He et al., 1998; van Heeswijk et al., 1996).

This work further examines roles of $\mathrm{GlnD}$ in $A$. vinelandii. Attempts were made to isolate true $g \ln D$ null mutants, with internal deletion/insertion mutations, because the $g \ln D$ mutant, MV17, that was initially studied contained $\operatorname{Tn} 5$ inserted about 80 bp upstream of the stop codon, very near to the $3^{\prime}$ end of this large gene (2700 bp) (Contreras et al., 1991). While MV17 was $\mathrm{Nif}^{-}$, both GS and NtrC activities appeared to be normally regulated. The truncated $\mathrm{Gln} D$ protein in MV17 may therefore have retained GlnD function(s) 
associated with GS and NtrC activities but not with its influence on the NifL/NifA regulatory interaction. It is likely that GS and NifL/NifA activities are determined by the uridylylation state of GlnK, the only PII-like protein apparently present in A. vinelandii (P. Rudnick, unpublished). The designation of $g \ln K$ in $A$. vinelandii was based on the greater similarity of its gene product to GlnK proteins in other organisms and on the location of $g \ln K$ upstream of $a m t B$, encoding a methylammonium membrane transport protein, an organization that occurs in several other proteobacterial species (Meletzus et al., 1998; Jack et al., 1999; Thomas et al., 2000). The use of MV17 to define a role for GlnD in nif gene regulation in $A$. vinelandii was further compromised by the occurrence of an uncharacterized $g \ln D$-linked suppressor mutation that restored good growth on $\mathrm{N}$ sufficient medium in this strain as compared to the original poor growth phenotype in MV16 from which MV17 arose (Santero et al., 1988). The glnD null mutations reported here, with interposon mutations in the $5^{\prime}$ and central regions, could replace the wild-type $g \ln D$ gene after transformation into $A$. vinelandii, but strains carrying only the mutated $g \ln D$ gene could not be isolated unless a second mutation occurred, either spontaneously or by design, resulting in the inability of GS to be adenylylated.

\section{METHODS}

Bacterial strains and growth conditions. Strains and plasmids are shown in Table 1. Azotobacter vinelandii strains were grown aerobically at $30{ }^{\circ} \mathrm{C}$ in Burk's medium (Newton et al., 1953) with $1 \%$ sucrose (BS); BSN contained $15 \mathrm{mM}$ ammonium acetate, BSU contained $10 \mathrm{mM}$ urea $\mathrm{BSNO}_{3}$ contained $10 \mathrm{mM} \mathrm{KNO}_{3}$. Glutamine was included in competence and selective media at $1 \mathrm{mg} \mathrm{ml}^{-1}$ where indicated. Antibiotics for selection of recombinant $A$. vinelandii strains were added at the following concentrations: ampicillin $50 \mu \mathrm{g} \mathrm{ml}^{-1}$; kanamycin $2 \mu \mathrm{g} \mathrm{ml}^{-1}$; streptomycin $0.5 \mu \mathrm{g} \mathrm{ml}^{-1}$; tetracycline $2.5 \mu \mathrm{g}$ $\mathrm{ml}^{-1}$.

Construction and transformation of mutations in the $g \ln D$ gene of $\boldsymbol{A}$. vinelandii. Plasmids pSS166 or pRCS1 were mutagenized with either the $\operatorname{KIXX}\left(\operatorname{Kan}^{\mathrm{r}}\right)$ or the $\Omega\left(\operatorname{Str}^{\mathrm{r}}\right)$ cassettes at or between different restriction sites, thereby creating insertion or deletion/insertion mutations (Fig. 1). Plasmids were transformed into A. vinelandii competent cells on solid competence medium (Bali et al., 1992) with and without added glutamine. Amp $\mathrm{p}^{\mathrm{s}}$ transformants were those in which a double crossover event leading to gene replacement had occurred (bla was located on the suicide vectors). These were serially subcultured several times on BSN + Kan or $\mathrm{BSN}+$ Str. DNA was prepared from transformant or wildtype strains as described by Hopwood et al. (1985).

For complementation experiments plasmids pLAFR3 and pPR803 were conjugated into A. vinelandii MV72 and MV71 strains by triparental mating with $E$. coli and the transformants were selected on the basis of resistance to tetracycline (Kennedy \& Drummond, 1985).

Construction of gInA (GSY407F) mutants. Site-directed substitution of codon TAC (Tyr) with codon TTC (Phe) was achieved by elongation of a mutagenic primer. Plasmid pAG401, in which the $g \ln A$ gene of $A$. vinelandii was cloned by ligation of a $0.6 \mathrm{~kb}$ Pst $\mathrm{I}-E c o \mathrm{RI}$ fragment from pAT512 into pTZ19, was used as template. It was confirmed by sequencing

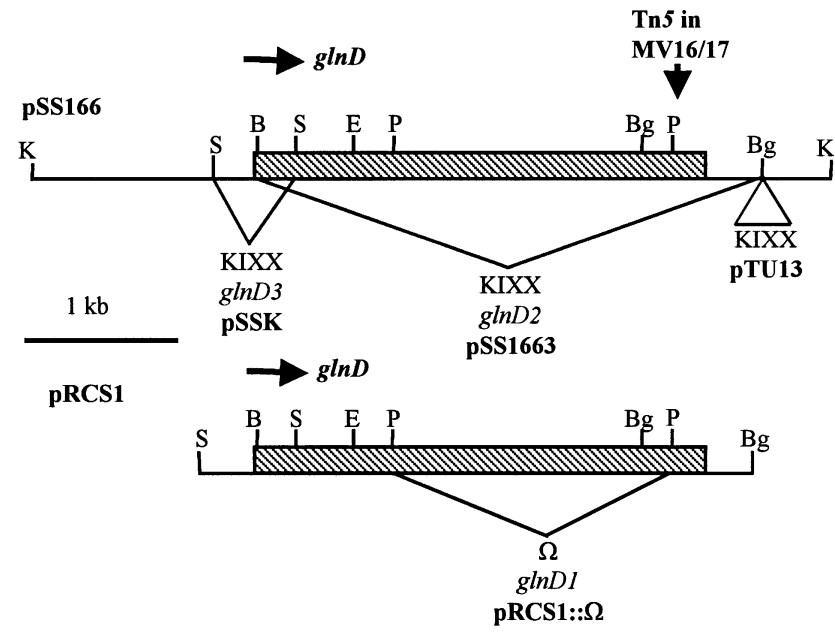

Fig. 1. Map of mutations in the $A$. vinelandii $g \ln D$ region. The $4.7 \mathrm{~kb} K p n l$ fragment containing the $g / n D$ gene was cloned in pTZ18 to give pSS166; the $3.3 \mathrm{~kb} K$ pnl-BamHI fragment was cloned into pBluescript to give pRSC1. Sites of deletion and insertion of $\Omega$ and KIXX cassettes and the position of insertion of Tn5 in the original glnD mutant MV17 are indicated. The horizontal arrow indicates direction of transcription of the $g \ln D$ gene. Restriction sites are abbreviated as follows: $\mathrm{B}, \mathrm{BamHI} ; \mathrm{Bg}$, Bg/ll; K, Kpnl; P, Pstl; S, Sall.

that one plasmid, pAG444, contained the mutated $g \ln A$ gene. Plasmid pAG444 was transformed into $A$. vinelandii in order to insert the mutated $g \ln A$ gene into the bacterial chromosome by a single cross-over event, leading to co-integration of the glnAY407F plasmid. One such strain was named MV74.

GS assays. A. vinelandii cultures for GS activity measurement were typically grown for $20-30 \mathrm{~h}$ in $20 \mathrm{ml} \mathrm{BSU} ; 15 \mathrm{mM}$ ammonium acetate was added when they reached an $\mathrm{OD}_{600}$ of $0 \cdot 6-0 \cdot 8$ and then removed $30 \mathrm{~min}$ later by centrifugation of cells and resuspension in $\mathrm{N}$-free medium. Six-millilitre samples of culture were taken before addition of ammonium, $30 \mathrm{~min}$ after its addition and $30 \mathrm{~min}$ after its removal. Cells were harvested and resuspended in $200 \mu \mathrm{l} 1 \% \mathrm{KCl}$. GS $\mathrm{Mn}^{2+}$ dependent transferase and $\mathrm{Mg}^{2+}$-dependent synthetic activities were measured at $\mathrm{pH} 7 \cdot 15$ and $7 \cdot 6$, respectively, using the reaction mixture (containing $0 \cdot 1 \mathrm{mg}$ cetyltrimethylammonium bromide $\mathrm{ml}^{-1}$ for cell lysis) described by Bender et al. (1977). At these $\mathrm{pHs}$, the transferase and synthetase activities showed the strongest changes in response to the degree of GS adenylylation (Kleinschmidt \& Kleiner, 1978, 1981). One unit of GS activity is the amount of enzyme producing $1 \mu \mathrm{mol} \gamma$ glutamyl hydroxamate $\mathrm{min}^{-1}$. Activities for all strains were determined several times; the data in Fig. 3 are from a single representative experiment.

In vitro uridylylation and Western blot analysis. Crude protein extracts were prepared from $25 \mathrm{ml}$ of saturated BSN cultures $\left(\mathrm{OD}_{600} 0 \cdot 8-1 \cdot 0\right)$. Cells were harvested and resuspended in $500 \mu \mathrm{l} 50 \mathrm{mM}$ Tris/ $\mathrm{HCl}, \mathrm{pH} 7 \cdot 5$, containing $100 \mathrm{mM} \mathrm{KCl}$ and $10 \mathrm{mM} \mathrm{MgCl}_{2}$, then disrupted by sonication. Uridylylation of PII in extracts was determined as described previously (Atkinson et al., 1994; Kamberov et al., 1995). To $92 \mu \mathrm{l}$ crude extract were added $0.1 \mathrm{mM}$ ATP, $1 \mathrm{mM}$ DTT, $0.1 \mathrm{mM} 2$ oxoglutaric acid, $\mathrm{pH} 7 \cdot 5$, and $5 \mu \mathrm{l}\left[\alpha^{-32} \mathrm{P}\right] \mathrm{UTP}\left(1 \cdot 1 \times 10^{4} \mathrm{~Bq}\right)$ (Amersham). Mixtures were incubated for $2 \mathrm{~h}$ at $30^{\circ} \mathrm{C}$ and the reaction stopped by the addition of EDTA $(10 \mathrm{mM})$. Proteins were separated by SDS-PAGE and transferred to a Duralose membrane for subsequent exposure to X-ray film. Western 
analysis was performed using the Immun-Blot Assay Kit (Bio$\mathrm{Rad})$. Treated membranes were incubated with E. coli anti-PII (gift from W. van Heeswijk), diluted 1:2500, for $2.5 \mathrm{~h}$ at room temperature. Anti-rabbit IgG alkaline phosphatase conjugate was added and after $2 \mathrm{~h}$, cross-reacting proteins were identified by adding substrate for alkaline phosphatase activity. Signal intensities were quantified using the Molecular Dynamics ImageQuant software package.

\section{RESULTS}

\section{Attempts to construct stable glnD null mutants}

A. vinelandii wild-type strain UW136 was transformed with $g \ln D$ insertion/deletion mutations, removing the central, entire or $5^{\prime}$ regions of $g \ln D$, carried on the $\mathrm{Amp}^{\mathrm{r}}$ suicide vectors $\mathrm{pTZ18R}$ or pBluscriptII unable to replicate in this host: $\mathrm{pRCS} 1:: \Omega \quad(g \ln D 1:: \Omega$; $\left.\operatorname{Str}^{\mathrm{r}}\right), \quad \mathrm{pSS} 1663\left(g \ln D 2:: \mathrm{KIXX} ; \mathrm{Kan}^{\mathrm{r}}\right)$ and pSSK $\left(g \operatorname{lnD} 3:: \mathrm{KIXX} ; \operatorname{Kan}^{\mathrm{r}}\right)$ (Fig. 1). Kan ${ }^{\mathrm{r}}$ or $\mathrm{Str}^{\mathrm{r}}$ transformants (grown with or without $10 \mathrm{mM}$ glutamine) were screened for ampicillin sensitivity; $\mathrm{Amp}^{\mathrm{s}}$ (vectorfree) isolates were subsequently subcultured at least three times on the antibiotic used for initial selection. Several Str ${ }^{\mathrm{r}}$ Amp $\mathrm{s}$ p CS1:: $\Omega$ transformants in which the mutated $g \ln D$ gene had presumably replaced the wildtype allele by a double recombination event were analysed by Southern hybridization. In all colonies, two $K p n I$ fragments hybridized to a $g \ln D$ probe: a $4.7 \mathrm{~kb}$ band corresponding to the wild-type $g \ln D$ region and a $5 \cdot 2 \mathrm{~kb}$ band, representing the $g \ln D 1:: \Omega$ mutated region (Fig. 2a). These results indicate that the transformants contained both wild-type and mutated copies of $g \ln D$. It is possible for both to be present in the same cell on different chromosomes because $A$. vinelandii often carries multiple chromosomal copies (Maldonado et al., 1994). In addition, 10 to 50 individual colonies of pRC1:: $\Omega$, pSS1663 and pSSK transformants were tested for retention of $\operatorname{Kan}^{\mathrm{r}}$ or $\operatorname{Str}^{\mathrm{r}}$ after three subcultures on antibiotic-free medium. All A. vinelandii transformants obtained lost antibiotic resistance after only one subculture on BSN agar without antibiotics. These two criteria, instability of antibiotic resistance and retention

(a)

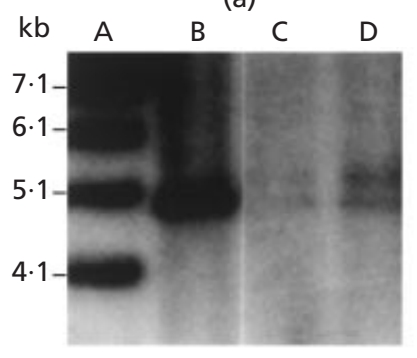

(b)

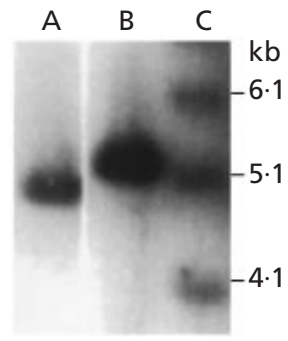

Fig. 2. Southern blot analysis of $g \ln D:: \Omega$ transformants. DNA was prepared from strains, digested with $K p n l$ and run on $0.8 \%$ agarose gels for fragment separation. The probe was a $700 \mathrm{bp}$ BamHI-EcoRI fragment from pSS166 labelled with [ $\left.{ }^{32} \mathrm{P}\right] \mathrm{dCTP}$ in a random-primed polymerase reaction (Stratagene). (a) Lane $A$, $1 \mathrm{~kb}$ ladder (Gibco); lane B, wild-type UW136; lanes C and D, two 'unstable' gInD:: $\Omega$ transformants. (b) lane A, UW136; lane B, MV71; lane C, 1 kb ladder (Gibco). of wild-type and mutated copies of chromosomes after many generations of selective growth, were previously used to establish the lethality of other cassette-insertion null mutations in $A$. vinelandii (Toukdarian et al., 1990; Meletzus et al., 1998; Zheng et al., 1998).

The pTU13 transformants (KIXX inserted downstream of the $g \ln D$ coding region, Fig. 1) were stably $\mathrm{Nif}^{+}$and retained $\operatorname{Kan}^{\mathrm{r}}$ after many generations in non-selective medium. Southern blot analysis of the DNA of one isolate tested showed that only the mutated region, and not the wild-type, was present in its genome (data not shown). This indicates that the instability of antibiotic resistance observed in transformants derived using pSS1663, pSSK or pRCS1:: $\Omega$ is due to interruption of $g \ln D$ itself and not due to interference with expression of any gene downstream from $g \ln D$.

\section{Isolation and analysis of a stable $A$. vinelandii glnD internal deletion mutant}

In one experiment in which $A$. vinelandii was transformed with $\mathrm{pRCS} 1:: \Omega$, a single $\operatorname{Str}^{\mathrm{r}} \mathrm{Amp} \mathrm{p}^{\mathrm{s}}$ transformant appeared as a much larger colony than usual. In this isolate, MV71, Str resistance was not lost as had usually occurred with pRCS1:: $\Omega \operatorname{Str}^{\mathrm{r}} \mathrm{Amp} \mathrm{p}^{\mathrm{s}}$ transformants after cycles of growth on a medium without Str. In addition, while unstable $g \ln D 1:: \Omega$ mutant transformants were small and irregularly shaped, MV71 colonies looked nearly the same as wild-type, though they were smaller on ammonium-containing medium. In Southern hybridization analysis of MV71 genomic DNA, the $g \ln D$ probe hybridized only to a $5 \cdot 2 \mathrm{~kb} K p n \mathrm{I}$ fragment, the size of the $g \ln D 1:: \Omega$ fragment (Fig. 2b). These results show that replacement of the wild-type gene with the $\ln D 1:: \Omega$ allele had occurred in MV71, and that chromosomes carrying wild-type $g \ln D$ genes were undetectable. In addition, MV71 colonies were $\mathrm{Nif}^{-}$.

The appearance of this rare, stable $g \ln D 1:: \Omega$ null mutant, MV71, among a background of several hundred unstable mutants suggested that a second, compensating mutation in an unknown gene had occurred in this strain; this mutant allele was designated $g l n-71$. To separate the $g \ln D 1:: \Omega$ and $g \ln$-71 alleles, MV71 was first transformed with plasmid pSS166 carrying the wildtype $g \ln D$ gene, followed by selection on BS medium without antibiotics. All $\mathrm{Nif}^{+}$transformants were $\mathrm{Amp}^{\mathrm{s}}$ $\mathrm{Str}^{\mathrm{S}}$ and represented strains in which the $g \ln \mathrm{D} 1:: \Omega$ allele was replaced with wild-type $g \ln D$ by homologous recombination. One such transformant carrying only the $g \ln -71$ mutation and not the $g \ln D 1:: \Omega$ allele was named MV72. The only phenotype noted for MV72 was a longer lag phase and slower growth rate in liquid BSN and smaller colony formation on solid BSN than occurred with the wild-type strain. The growth rate of MV72 on N-free medium was similar to that of the wild-type strain. MV72 transformed with $\mathrm{pRCS1:: \Omega}$ $(g \ln D 1:: \Omega)$ resulted in $\operatorname{Str}^{\mathrm{r}} \mathrm{Amp} \mathrm{s}^{\mathrm{s}}$ transformant colonies (30 tested) that were unable to fix nitrogen and had the same colony morphology as the original MV71 mutant, confirming that MV72 contains a mutation capable of 


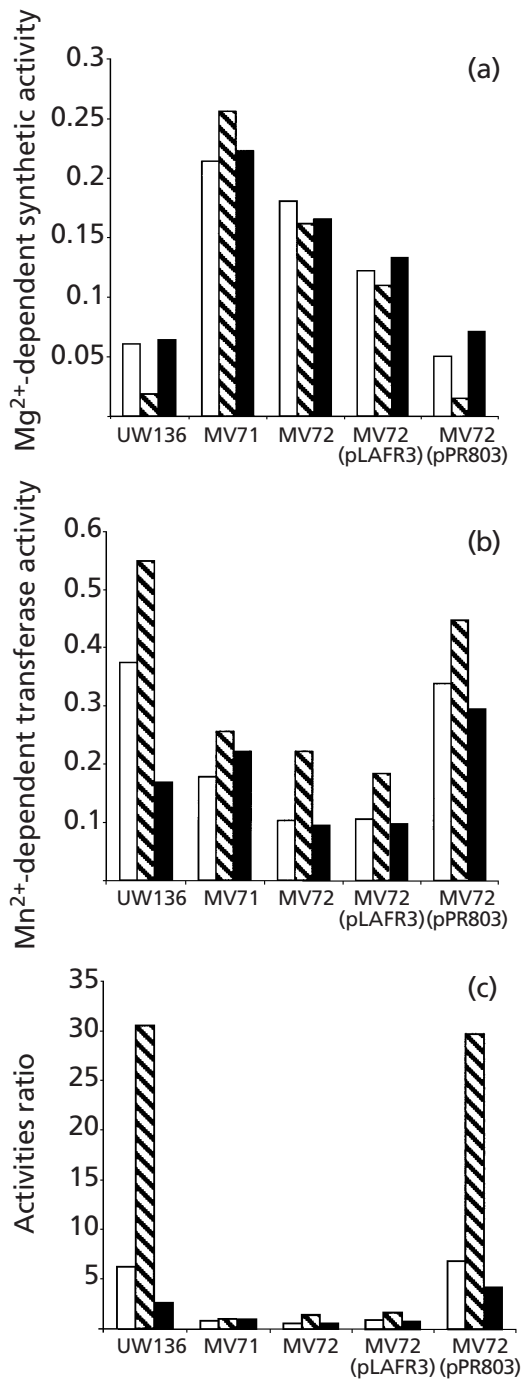

Fig. 3. GS activities in wild-type, mutant and transformant strains. Strains were grown and assayed as described in Methods. (a) $\mathrm{Mg}^{2+}$-dependent transferase activity; (b) $\mathrm{Mn}^{2+}$ dependent synthetic activity; (c) activities ratio $\left(\mathrm{Mn}^{2+}\right.$ dependent/ $\mathrm{Mg}^{2+}$-dependent). $\square$, Activity before addition of $\mathrm{NH}_{4}^{+} ; \nabla$, activity after addition of $\mathrm{NH}_{4}^{+} ; \boldsymbol{\square}$, activity after removal of $\mathrm{NH}_{4}^{+}$.

stabilizing the $g \ln D$ null mutation by suppressing its very deleterious or lethal effect in A. vinelandii.

\section{GS activity of MV71 and MV72}

Two other deleterious/lethal insertion mutations were those in $g \ln A$ encoding GS or in $g \ln K$ (Toukdarian et al., 1990; Meletzus et al., 1998). Because GS is an essential enzyme in $A$. vinelandii, and since $\mathrm{G} \ln \mathrm{D}$ in enteric bacteria influences the activity state of GS through modulation of the activity of the GlnE protein, which adenylylates/deadenylylates GS, it seemed possible that the gln-71 mutation in MV71 and MV72 might affect GS catalytic behaviour. The degree of GS adenylylation was qualitatively estimated from the ratio of the $\mathrm{Mn}^{2+}$ dependent transferase activity at $\mathrm{pH} 7 \cdot 15$ to the $\mathrm{Mg}^{2+}$ - dependent synthetic activity at pH 7.6 (Kleinschmidt \& Kleiner, 1978, 1981). At these $\mathrm{pH}$ values both activities showed the strongest and inverse changes in response to the degree of GS adenylylation (Kleinschmidt \& Kleiner, 1978). When ammonium was added to cultures of the wild-type strain UW136, the activities ratio increased about fivefold, indicating GS adenylylation (Fig. 3c). After removal of ammonium, the activities ratio decreased to approximately the original value, indicating GS deadenylylation. In contrast, the activities ratio of both MV71 and MV72 strains remained very low and little change was observed upon addition and subsequent removal of ammonium from cultures, indicating that in the $g \ln -71$ strains, the regulation of GS activity via adenylylation was altered. The $\mathrm{Mg}^{2+}$ dependent synthetic activity and the $\mathrm{Mn}^{2+}$-dependent transferase activity of either MV72 or MV71 were respectively higher and lower than wild-type (Fig. 3a, b). This can be explained by considering the fact that in both mutant strains GS is hyperactive.

\section{The $g / n-71$ mutation is probably located in the $g / n E$ gene}

Candidate genes in which the $g \ln -71$ mutation might have occurred include $g \ln A$ (e.g. a mutation preventing adenylylation of Tyr407), $g \ln K$ (e.g. a mutation resulting in a GlnK-UMP-like conformation), or $g \ln E$ (e.g. a null mutation inactivating the GS-adenylylation function of $\mathrm{G} \ln \mathrm{E})$. Another possibility was that the $g \ln -71$ mutation was in an unknown gene or regulatory region linked to $g \ln D$.

Linkage between $g \ln -71$ and $g \ln D$ was ruled out by transformation experiments in which MV71 DNA was used to transform the wild-type strain UW136. When the amount of donor DNA added to competent cells was just sufficient to yield 50-100 $\mathrm{Str}^{\mathrm{r}}$ transformants per plate, all of the approximately 1000 colonies obtained were small in size and unstable with respect to streptomycin resistance, indicating that cotransformation of $g \ln -71$ with $g \ln D$ did not occur with significant frequency.

To determine whether the $g \ln -71$ mutation occurred within $g \ln A$ or $g \ln K$, DNA from these regions of MV72 was sequenced. Each sequence in both strains was identical to the wild-type gene. Attempts to identify and clone the $g \ln E$ gene of $A$. vinelandii by Southern hybridization using the E. coli glnE gene as probe or by PCR strategies based on GlnE amino acid similarities in other prokaryotes were unsuccessful. An alternative strategy was to try to complement the unregulated GS activity phenotype of MV72 by introducing the E. coli $g \ln E$ gene on a wide-host-range plasmid. To achieve this, the $5 \mathrm{~kb}$ BamHI-Pst I fragment from plasmid pDK805 (van Heeswijk et al., 1993) carrying the E. coli $g \ln E$ gene was subcloned into vector pLAFR3 (Peet et al., 1986), resulting in pPR803. Plasmid pPR803 restored adenlylation/deadenylylation of GS in MV72 (Fig. 3c), indicating that the mutation stabilizing the $g \ln D$ phenotype is most probably located in $g \ln E$. 
An experiment to further test the idea that the $g \ln -71$ mutation is located in $g \ln E$ was based on the idea that if the lethality of the $g \ln D 1:: \Omega$ allele was suppressed by a mutation in $g \ln E$, then the stable mutant MV71 carrying both the $g \ln D 1:: \Omega$ and $g \ln -71$ alleles should be unable to yield viable transformants carrying pPR803. Plasmids pPR803 and pLAFR3 were independently conjugated into both MV71 $(g \ln D 1:: \Omega g \ln -71)$ and MV72 $(g \ln -71)$ strains by triparental mating (see Methods). MV72 yielded several hundred $\mathrm{Tet}^{\mathrm{r}}$ colonies after conjugation with either pPR803 or pLAFR3. MV71(pLAFR3) Tet ${ }^{r}$ transformants also numbered in the hundreds but no $\mathrm{Tet}^{\mathrm{r}}$ colonies arose from conjugation of MV71 cells with pPR803, indicating that introduction of the E. coli glnE gene which restored the ability of GS to be adenylylated was 'lethal' and could not be harboured in the $g \ln D 1:: \Omega$ gln-71 background.

Consistent with the conclusion that the gln-71 mutation is in the $g \ln E$ gene is the fact that the poor growth phenotype of MV71 and MV72 on BSN medium is similar to that shown by $g \ln E$ mutants of Salmonella typhimurium (Kustu et al., 1984). Poor growth by these mutants was attributed to a deficiency of glutamate due to its hyperconversion to glutamine. In addition, mutations in $g \ln E$ suppressed the glutamine auxotrophy of $g \ln D$ mutants in S. typhimurium (Bancroft et al., 1978).

\section{Construction of $g \ln A$ (GSY407F) $g \ln D:: \Omega$ double mutants}

In parallel experiments to test the hypothesis that $g \ln D$ null mutations were lethal because GS cannot be deadenylylated in the absence of $\mathrm{G} \operatorname{lnD}$, the site of GS adenylylation was altered by mutagenesis of $g \ln A$ (see Methods). A $g \ln A Y 407 F$ strain, MV74, grew well in BS medium but not in liquid BSN medium and only very small colonies formed on BSN agar; again this is probably related to a glutamate deficiency as for the $g l n$ $71(g \ln E)$ mutant. As in MV71 and MV72, little change of GS catalytic behaviour occurred in MV74 upon addition or removal of $\mathrm{NH}_{4}^{+}$from the medium (data not shown). MV74 was then transformed with the $g \ln D 1:: \Omega$ plasmid pRCS1:: $\Omega$. Several hundred $\operatorname{Str}^{\mathrm{r}}$ transformants, about half of which were $A m p^{\mathrm{s}}$ indicating $g \ln D$ gene replacement by a double crossover event, appeared as large colonies on BSU Str medium and did not lose their Str resistance after several cycles of growth on nonselective medium. Southern blot analysis confirmed the complete substitution of wild-type $g \ln D$ with the $\operatorname{gln} D 1:: \Omega$ allele in a representative $\operatorname{Str}^{\mathrm{r}} \mathrm{Amp}^{\mathrm{s}}$ isolate, MV75 (data not shown), indicating that like $g \ln -71$, $g \ln A Y 407 F$ can stabilize a $g \ln D$ null mutation.

\section{Influence of $g \ln D$ mutations on nif gene regulation and NtrC phenotype}

As with the original $g \ln D:: \operatorname{Tn} 5$ mutant MV17 (Santero et al., 1988), neither MV71 nor MV75, the two stable glnD null mutants characterized here, was able to grow

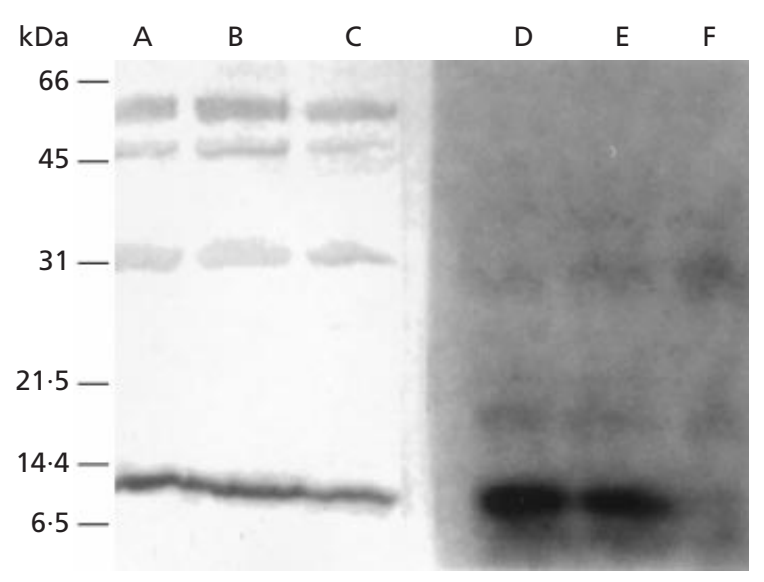

Fig. 4. In vitro uridylylation and immunoblotting analysis of $A$. vinelandii GInK. Following an in vitro uridylylation reaction, proteins of the cell-free extracts were separated by SDS-PAGE and transferred to Duralose membranes for exposure to X-ray film (lanes $D$ to $F$ ). The same blot was then incubated with $E$. coli anti- $P_{\|}$serum for Western analysis (lanes $A$ to $C$ ). Lanes $A$ and D, UW136 (wild-type); lanes B and E, MV17 (glnD16::Tn5);

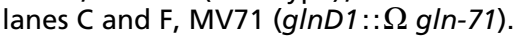

on $\mathrm{N}$-free media (solid or liquid) and they had little or no detectable nitrogenase activity, as measured by acetylene reduction (data not shown). The $\mathrm{Nif}^{-}$phenotypes of MV71 and MV75 were suppressed (i.e. became $\mathrm{Nif}^{+}$) by introduction of the nifL1::KIXX deletion/ insertion mutation (Bali et al., 1992; Blanco et al., 1993), or, in the case of MV71, by introduction of pCK1 expressing the Klebsiella pneumoniae nifA gene constitutively (Kennedy \& Robson, 1983). This result confirms that the $A$. vinelandii $g \ln D$ gene product is required for the relief of the NifL inhibition of NifA that normally occurs in cells grown under N-limiting conditions.

Because $g \ln D$ null mutants of enteric bacteria are generally $\mathrm{Ntr}^{-}$, the stable $g \ln D$ null mutants MV71 and MV75, and also MV17 [ $g \operatorname{lnD} 16:: \operatorname{Tn} 5]$, were examined for growth on nitrate as an indicator of $\mathrm{NtrC}$ activity (Toukdarian \& Kennedy, 1986). Tests included growth on $\mathrm{BSNO}_{3}$ agar medium and also liquid medium derepression experiments in which the lag time and subsequent growth rate after shift from $\mathrm{BSN}$ to $\mathrm{BSNO}_{3}$ was determined. All three $g \ln D$ mutants grew on $\mathrm{BSNO}_{3}$ at a rate indistinguishable from wild-type UW136 and had no longer lag time after the shift from BSN to $\mathrm{BSNO}_{3}$ (data not shown), indicating an $\mathrm{NtrC}^{+}$phenotype.

\section{Uridylylation of GlnK and Western blot analysis}

The GlnK protein of A. vinelandii was labelled in cellfree extracts to which $\left[\alpha^{3}{ }^{32} \mathrm{P}\right] \mathrm{UTP}$ and 2-oxoglutarate were added. As shown in Fig. 4, labelling of a $12 \mathrm{kDa}$ protein was observed in cell-free extracts of wild-type and MV17 strains; the extent of label in the $12 \mathrm{kDa}$ 
protein in MV17 was about $60 \%$ of that appearing in wild-type extracts (determined by Quant Image Analysis). No $\left[{ }^{32} \mathrm{P}\right]$ UTP incorporation was detected in the stable $\Delta g \ln D g \ln -71$ strain MV71. Similar amounts of GlnK protein were present in wild-type and in MV17 extracts, as shown by Western blots treated with polyclonal antibody prepared against the PII protein from E. coli. Slightly less $12 \mathrm{kDa}$ protein was detected in MV71 extracts, approximately $75 \%$ of that found in the other two strains. That uridylyltransferase activity of GlnD was present in MV17 confirms the hypothesis that $\mathrm{G} \ln \mathrm{D}$ in this mutant was not completely inactivated by the Tn5 insertion or that the activity was at least partially restored by the uncharacterized suppressor mutation that occurred in MV16, leading to MV17. Unfortunately, stored cultures of MV16 were not viable and it was not possible to distinguish between these two possibilities.

\section{DISCUSSION}

A. vinelandii represents a model system among Eubacteria for analysing mutations in essential genes. Retention of both mutant and wild-type copies of chromosomes can occur and be detected in A. vinelandii because it can harbour a large number of chromosomes, up to 80 or more, depending on growth conditions (Maldonado et al., 1994). The great majority of null mutations in $A$. vinelandii genes have been easily introduced and have fully replaced the wild-type alleles; these are too numerous to detail here but include many nif, ntr, cyd, vnf, anf and hup genes. The first case of an apparently lethal mutation in $A$. vinelandii was the finding that mutations in the $g \ln A$ gene encoding GS, created by insertion of Tn 5 or other elements, could replace the wild-type gene but were maintained in only a fraction of the chromosomes and only under antibiotic selection for the insertion element (Toukdarian et al., 1990). The lethality of $g \ln A$ null mutations in $A$. vinelandii was explained by the inability of this organism to transport glutamine and the absence of other pathways for ammonium assimilation (Kennedy \& Toukdarian, 1987). Other examples of essential genes in A. vinelandii include $g \ln K$ (Meletzus et al., 1998) and also isc genes encoding proteins involved in ironsulphur cluster formation (Zheng et al., 1998). glnD can now be added to the list.

The most probable explanation for the failure to establish $g \ln D$ null mutations in $A$. vinelandii is the requirement of $\mathrm{G} \ln \mathrm{D}$ protein for uridylylation of $\mathrm{G} \ln K$, which in turn is required for deadenylylation of GS. Alteration of the adenylylation site Tyr407 to Phe in the GS protein allows the $g \ln D$ null mutations to stably replace the wild-type allele. Also, the spontaneously arising stable $g \ln D$ mutant strain, MV71, carries a second-site mutation, $g \ln -71$, which is probably located within $g \ln E$ and results either in a lack of both ATase and adenylyl-removing activities of GlnE or in a GlnE which is locked in the latter conformation and fails to respond to ammonium. It was previously shown that gln $A$ null mutations could not be established in $A$. vinelandii, even in the presence of added glutamine (Toukdarian et al., 1990) and that glutamine was not significantly transported into $A$. vinelandii cells in $\left.{ }^{[14} \mathrm{C}\right]$ glutamine uptake experiments. In the current work, the addition of glutamine also did not allow establishment of the $g \ln D$ null mutations (Toukdarian et al., 1990). Taken together, these results confirm that GS in A. vinelandii is an essential enzyme for the biosynthesis of glutamine and ammonium assimilation.

Amongst enteric bacteria, $g \ln D$ mutants, which are generally $\mathrm{NtrC}^{-}$, adenylylate GS faster and deadenylylate it more slowly than wild-type organisms, and the extent to which glutamine is required for growth varies considerably (Bancroft et al., 1978; Foor et al., 1978; Bueno et al., 1985; Edwards \& Merrick, 1995 ; Atkinson \& Ninfa, 1998). Based on these general phenotypes, it was expected that $A$. vinelandii $g \ln D$ null mutants might be less able to grow on nitrate (the only $\mathrm{NtrC}^{-}$ phenotype identified in this organism: Toukdarian \& Kennedy, 1986), and that GS might be deadenylylated at a rate slower than in the wild-type. However, no effect on growth on nitrate was observed in the viable $g \ln D$ mutants MV71 $(g \ln D 1:: \Omega g \ln -71)$ or MV75 $(g \ln D 1:: \Omega$ $g \ln A Y 407 F)$. In contrast, the physiological effect of $g \ln D$ mutations in A. vinelandii on the inability of GS to be deadenylylated appears to be more drastic than in the enteric $g \ln D$ mutants. The inability to isolate stable $g \ln D$ mutants of $A$. vinelandii at all unless a second mutation occurred resulting in inability of GS to be adenylylated is evidence for this. The target proteins, $\mathrm{NtrB}$ and GlnE, of A. vinelandii may be less and more, respectively, sensitive to the influence of GlnK or GlnK$\mathrm{UMP}$ in A. vinelandii than to $\mathrm{G} \ln B$ or $\mathrm{G} \ln \mathrm{K}$ (or their uridylylated forms) in enteric organisms. Alternatively, the apparent $\mathrm{NtrC}^{+}$phenotype of $A$. vinelandii $g \ln D$ mutants might be explained by there being sufficient 2oxoglutaric acid in cells grown in nitrate to inhibit the phosphatase activity of $\mathrm{NtrB}$, resulting in the inability of NtrC to be dephosphorylated (Jiang \& Ninfa, 1999).

That the $g \ln D:: \operatorname{Tn} 5$ mutation located at the $3^{\prime}$ end of the $g \ln D$ gene in MV17 did not severely influence the ability of the mutant strain to uridylylate GlnK indicates that the transferase activity does not involve the $\mathrm{C}$-terminal region of the protein. $\mathrm{G} \ln \mathrm{D}$ is very large, $>100 \mathrm{kDa}$ and was shown by Jiang et al. (1998) to have both uridylyltransferase and uridylyl-removing activities located within the same active site. It is relevant in this context that, as for A. vinelandii, $g \ln D$ null mutants also could not be isolated in Sinorhizobium (Rhizobium) meliloti (P. Rudnick and others, unpublished) or in the Gram-positive Corynebacterium glutamicum (Jakoby et al., 1999). In the case of $R$. meliloti, the apparent lethality is not related to the adenylylation state of GS, as is shown here for $A$. vinelandii, because a $g \ln A 1$ mutant with a Y407F substitution that prevents GS adenylylation (Arcondeguy et al., 1996) did not provide a background in which stable and viable $g \ln D:: \mathrm{spc}$ mutants could be isolated (P. Rudnick \& D. Kahn, unpublished results). Also, in Acetobacter diazo- 
trophicus, $g \ln D$ insertion mutations resulted in formation of very tiny colonies after several days of growth (Perlova et al., 2000). Whether this suggests an essential or near-essential role for GlnD other than that for PII- or GlnK-uridylylation, or one for PII-UMP or GlnK-UMP, remains to be determined. Recent connections between GlnD and cell division, in which $g \ln D 99:: \operatorname{Tn} 10$ suppressed the lethality of a temperature sensitive $f t s Z$ mutation (Powell \& Court, 1998), and between GlnD and polyphosphate accumulation, which is believed to prevent stress-induced damage (Ault-Riche et al., 1998), may provide clues. Also, a transposon insertion in the Vibrio fischeri glnD gene resulted in slower but variable growth rates depending on $\mathrm{N}$ source and, very interestingly, on an inability to synthesize siderophores for iron uptake (Graf \& Ruby, 2000). In contrast, $g \ln D$ null mutants of Rhizobium tropicii were apparently unaffected in general growth properties; however, only those with insertion mutations in the $5^{\prime}$ or central region of $g \ln D$ were unable to utilize nitrate as a $\mathrm{N}$ source and did not induce chlorosis in plants, a process that is regulated by fixed $\mathrm{N}$ (O'Connell et al., 1998). This result again reflects the complexity of $\mathrm{G} \ln \mathrm{D}$ and the apparent dispensability, at least in some cases, of the C-terminal region of the protein.

The $\mathrm{Nif}^{-}$phenotype of the $g \ln \mathrm{D}$ null mutants was, as for the original $g \ln D:: \operatorname{Tn} 5$ strain MV17, corrected to $\mathrm{Nif}^{+}$ by the introduction of the nifL1::KIXX mutation (Bali et al., 1992) or the plasmid pCK1, which constitutively expresses the nifA gene of K. pneumoniae (Kennedy \& Robson, 1983) (MV75 was not tested). This confirms the involvement of GlnD in relieving the inhibition of NifA by NifL in A.vinelandii. He et al. (1998) and Arcondeguy et al. (1999) recently showed that GlnD is required for relief of K. pneumoniae NifL inhibition of NifA activity in an E. coli background. The GlnD requirement is for uridylylation of PII, and PII-UMP is required to eliminate the PII-stimulated dephosphorylation of $\mathrm{NtrC}$ (Jiang \& Ninfa, 1999). NtrC-P is in turn needed for the expression of $g \ln K$. GlnK appears to be the only NtrC$\mathrm{P}$-activated gene required to modulate the NifL/NifA interaction and is required for relief of NifA inhibition by NifL in enteric bacteria (He et al., 1998; Jack et al., 1999). However, the uridylylation state of GlnK appears to be immaterial with respect to the NifL/NifA interaction (He et al., 1998; Arcondeguy et al., 1999). Therefore the only role for $\mathrm{GlnD}$ is apparently in ensuring that $\mathrm{NtrC}$ is phosphorylated and available for glnK transcription. Edwards \& Merrick (1995) had shown that GlnD was not required for relief of inhibition of NifA by NifL in an $n t r B 6$ strain that should express $g \ln K$ constitutively. In contrast, the requirement in $A$. vinelandii for $\mathrm{G} \ln \mathrm{D}$ to relieve inhibition of NifA activity by NifL does not involve NtrC, because $\mathrm{NtrC}$ is required neither for expression of the nifLA operon (Toukdarian \& Kennedy, 1986; Blanco et al., 1993), as it is in K. pneumoniae, nor for $g \ln K$ expression, implied from the fact that the $g \operatorname{lnKamtB}$ operon in $A$. vinelandii is expressed at very low levels under all conditions, regardless of fixed $\mathrm{N}$ supply (Meletzus et al., 1998).
Also, the $g \ln K$ promoter region shows no sequences similar to those recognized by $\mathrm{NtrC}$ and $\sigma^{\mathrm{N}}$, as are found upstream of the $g \ln K$ gene in $E$. coli and in $K$. pneumoniae. Therefore, the requirement of $\mathrm{GlnD}$ to relieve inhibition of NifA activity by NifL apparently occurs by a different mechanism in A. vinelandii than in the enteric organisms.

Is uridylylated GlnK protein in A. vinelandii required for relief of inhibition of NifA activity by NifL? Both $g \ln D$ mutant strains MV17, which can at least partially uridylylate GlnK, and MV71, which cannot detectably uridylylate $\mathrm{GlnK}$, are $\mathrm{Nif}^{-}$and are restored to $\mathrm{Nif}^{+}$by introduction of a nifL::KIXX mutation. These results might suggest that $\mathrm{GlnK}$ is not involved in the relief of inhibition of NifA activity by NifL or that its uridylylation state is irrelevant, as reported to be the case for enteric bacteria (He et al., 1998; Arcondeguy et al., 1999). It is conceivable that levels of GlnK-UMP in MV17 are sufficient to promote deadenylylation of GS, but not sufficient to relieve NifL inhibition of NifA under N-fixing conditions. Recent results with a $g \ln K Y 51 F$ mutant indicate that uridylylated $G \ln K$ is required for relief of inhibition of NifA activity by NifL in wild-type A. vinelandii but not in the nifL1:: KIXX mutant strain (P. Rudnick and others, unpublished). In addition, Little et al. (2000) recently demonstrated that unuridylylated PII-like proteins cause NifL to be inhibitory to NifA in an in vitro system.

\section{ACKNOWLEDGEMENTS}

This work has been supported by a grant from USDA NRI, number 95-37305-2067. We thank Dr W. van Heeswijk for the gift of antiserum to E. coli PII protein, Dr D. Kahn for critical reading of the manuscript and Dr E. Pierson for guidance in using Image Analysis software.

\section{REFERENCES}

Arcondeguy, T., Huez, I., Fourment, J. \& Kahn, D. (1996). Symbiotic nitrogen fixation does not require adenylylation of glutamine synthetase I in Rhizobium meliloti. FEMS Microbiol Lett 145, 33-40.

Arcondeguy, T., van Heeswijk, W. C. \& Merrick, M. (1999). Studies on the roles of GlnK and GlnB in regulating Klebsiella pneumoniae NifL-dependent nitrogen control. FEMS Microbiol Lett 180, 263-270.

Atkinson, M. R. \& Ninfa, A. J. (1998). Role of the GlnK signal transduction protein in the regulation of nitrogen assimilation in Escherichia coli. Mol Microbiol 29, 431-447.

Atkinson, M. R., Kamberov, E. S., Weiss, R. \& Ninfa, A. J. (1994). Reversible uridylylation of the Escherichia coli PII signal transduction protein regulates its ability to stimulate the dephosphorylation of the transcription factor nitrogen regulator I (NRI or NtrC). J Biol Chem 269, 28288-28923.

Ault-Riche, D., Fraley, C. D., Tzeng, C. M. \& Kornberg, A. (1998). Novel assay reveals multiple pathways regulating stress-induced accumulations of inorganic polyphosphate in Escherichia coli. J Bacteriol 180, 1841-1847.

Bali, A., Blanco, G., Hill, S. \& Kennedy, C. (1992). Excretion of 
ammonium by a nifL mutant of nitrogen fixing Azotobacter vinelandii. Appl Environ Microbiol 58, 1711-1718.

Bancroft, S., Rhee, S. G., Neumann, C. \& Kustu, S. (1978). Mutations that alter the covalent modification of glutamine synthetase in Salmonella typhimurium. J Bacteriol 134, 569-577.

Bender, R. A., Janssen, K. A., Resnick, A. D., Blumenberg, M., Foor, F. \& Magasanik, B. (1977). Biochemical parameters of glutamine synthetase from Klebsiella aerogenes. J Bacteriol 129, 1001-1009.

Bishop, P. E. \& Brill, W. J. (1977). Genetic analysis of Azotobacter vinelandii mutant strains unable to fix nitrogen. J Bacteriol 130, 954-956.

Blanco, G., Drummond, M. D., Kennedy, C. \& Woodley, P. (1993). Sequence and molecular analysis of the nifL gene of Azotobacter vinelandii. Mol Microbiol 9, 869-879.

Bueno, R., Pahel, G. \& Magasanik, B. (1985). Role of $g \ln B$ and $g \ln D$ gene products in regulation of the $g \ln A L G$ operon of Escherichia coli. J Bacteriol 164, 816-822.

Contreras, C., Drummond, M., Bali, A., Blanco, G., Garcia, E., Bush, G., Kennedy, C. \& Merrick, M. (1991). The product of the nitrogen fixation regulatory gene $n f r X$ of Azotobacter vinelandii is functionally and structurally homologous to the uridylyltransferase encoded by $g \ln D$ in enteric bacteria. J Bacteriol 173 , 7741-7749.

Edwards, R. \& Merrick, M. (1995). The role of uridylyltransferase in the control of Klebsiella pneumoniae nif gene regulation. Mol Gen Genet 247, 189-198.

Foor, F., Cedergren, R. J., Streicher, S. L., Rhee, S. G. \& Magasanik, B. (1978). Glutamine synthetase of Klebsiella aerogenes: properties of $g \ln D$ mutants lacking uridylyltransferase. J Bacteriol 134, 562-568.

Graf, J. \& Ruby, E. G. (2000). Novel effects of a transposon insertion in the Vibrio fischeri glnD gene: defects in iron uptake and symbiotic persistence in addition to nitrogen utilization. Mol Microbiol 37, 168-179.

He, L., Soupene, E., Ninfa, A. \& Kustu, S. (1998). Physiological role for the GlnK protein of enteric bacteria: relief of NifL inhibition under nitrogen-limiting conditions. J Bacteriol 180, 6661-6667.

van Heeswijk, W. C., Rabenberg, M., Westerhoff, H. V. \& Kahn, D. (1993). Genes of the glutamine synthetase adenylylation cascade are not regulated by nitrogen in Escherichia coli. Mol Microbiol 9, 443-457.

van Heeswijk, W. C., Stegeman, B., Hoving, S., Molenaar, D., Kahn, D. \& Westerhoff, H. V. (1995). An additional PII in Escherichia coli: a new regulatory protein in the glutamine synthetase cascade. FEMS Microbiol Lett 132, 153-157.

van Heeswijk, W., Hoving, S., Molenaar, D., Stegeman, B., Kahn, D. \& Westerhoff, H. V. (1996). An alternative PII protein in the regulation of glutamine synthetase in Escherichia coli. Mol Microbiol 21, 133-146.

Hopwood, D. A., Bibb, M. J., Kieser, T., Burton, C. J., Kieser, H. M., Lydiate, D. J., Smith, C. P., Ward, J. M. \& Schrempf, H. (1985). Genetic Manipulation of Streptomyces: a Laboratory Manual. Norwich, UK: John Innes Institute.

Jack, R., De Zamaroczy, M. \& Merrick, M. (1999). The signal transduction protein GlnK is required for NifL-dependent nitrogen control of nif gene expression in Klebsiella pneumoniae. J Bacteriol 181, 1156-1162.

Jaggi, R., van Heeswijk, W., Westerhoff, H. V., Ollis, D. L. \& Vasudevan, S. (1997). The two opposing activities of adenylyl transferase reside in distinct homologous domains, with intramolecular signal transduction. EMBO J 16, 5562-5571.
Jakoby, M., Kramer, R. \& Burkovski, A. (1999). Nitrogen regulation in Corynebacterium glutamicum: isolation of genes involved and biochemical characterization of corresponding proteins. FEMS Microbiol Lett 173, 303-310.

Jiang, P. \& Ninfa, A. J. (1999). Regulation of autophosphorylation of Escherichia coli nitrogen regulator II by the PII signal transduction protein. J Bacteriol 181, 1906-1911.

Jiang, P., Peliska, J. A. \& Ninfa, A. J. (1998). Enzymological characterication of the signal-transducing uridylyltransferase/ uridylyl-removing enzyme (EC 2.7.7.59) of Escherichia coli and its interaction with the PII protein. Biochemistry 37, 12782-12794.

Kamberov, E. S., Atkinson, M. R. \& Ninfa, A. J. (1995). The Escherichia coli PII signal transduction protein is activated upon binding 2-ketoglutarate and ATP. J Biol Chem 270, 17797-17807.

Kennedy, C. \& Drummond, M. H. (1985). The use of cloned nif regulatory elements from Klebsiella pneumoniae to examine nif regulation in Azotobacter vinelandii. J Gen Microbiol 131, 1787-1895.

Kennedy, C. \& Robson, R. (1983). Activation of nif gene expression in Azotobacter by the nifA gene product of Klebsiella pneumoniae. Nature 301, 626-628.

Kennedy, C. \& Toukdarian, A. (1987). Genetics of Azotobacters: applications to nitrogen fixation and related aspects of metabolism. Annu Rev Microbiol 41, 227-248.

Kleinschmidt, J. A. \& Kleiner, D. (1978). The glutamine synthetase from Azotobacter vinelandii: purification, characterisation, regulation and localisation. Eur J Biochem 89, 51-60.

Kleinschmidt, J. A. \& Kleiner, D. (1981). Relationship between nitrogenase, glutamine synthetase, glutamine, and energy charge in Azotobacter vinelandii. Arch Microbiol 128, 412-415.

Kustu, S., Hirschman, J., Burton, D., Jelesko, J. \& Meeks, J. C. (1984). Covalent modification of bacterial glutamine synthetase: physiological significance. Mol Gen Genet 197, 309-317.

Little, R., Reyes-Ramirez, F., Zhang, Y., van Heeswijk, W. C. \& Dixon, R. (2000). Signal transduction to the Azotobacter vinelandii NifL-NifA regulatory system is influenced directly by interaction with 2-oxoglutarate and the PII regulatory proteins. EMBO J 19, 6041-6050.

Maldonado, R., Jiminez, J. \& Casadesus, J. (1994). Changes of ploidy during the Azotobacter vinelandii growth cycle. J Bacteriol 176, 3911-3919.

Meletzus, D., Rudnick, P., Doetsch, N., Green, A. \& Kennedy, C. (1998). Characterization of the $g \ln K a m t B$ operon of Azotobacter vinelandii. J Bacteriol 180, 3260-3264.

Merrick, M. J. \& Edwards, R. A. (1995). Nitrogen control in bacteria. Microbiol Rev 59, 604-622.

Newton, J. W., Wilson, P. W. \& Burris, R. H. (1953). Direct demonstration of ammonia as an intermediate in nitrogen fixation by azotobacter. J Biol Chem 204, 445-451.

O'Connell, K. P., Raffel, S. J., Saville, B. J. \& Handelsman, J. (1998). Mutants of Rhizobium tropici strain CIAT899 that do not induce chlorosis in plants. Microbiology 144, 2607-2617.

Peet, R. C. , Lindgren, P. B., Willis, D. K. \& Panopoulos, N. J. (1986). Identification and cloning of genes involved in phaseolotoxin production by Pseudomonas syringae pv. 'phaseolicola'. J Bacteriol 166, 1096-1105.

Perlova, O., Ureta, A., Nordlund, S. \& Meletzus, D. (2000). Identification and characterization of genes involved in the ammonium sensing mechanism in Acetobacter diazotrophicus. In Nitrogen Fixation: from Molecules to Crop Productivity, p. 137. Edited by F. O. Pedrosa et al. Dordrecht: Kluwer. 
Powell, B. S. \& Court, D. L. (1998). Control of $f t s Z$ expression, cell division, and glutamine metabolism in Luria-Bertani medium by the alarmone ppGpp in Escherichia coli. J Bacteriol 180, 1053-1062.

Prentki, P. \& Krisch, H. M. (1984). In vitro mutagenesis with a selectable DNA fragment. Gene 29, 303-313.

Reitzer, L. J. (1996). Ammonia assimilation and the biosynthesis of glutamine, glutamate, aspartate, asparagine, L-alanine, and Dalanine. In Escherichia coli and Salmonella: Cellular and Molecular Biology, pp. 391-407. Edited by F. C. Neidhardt and others. Washington, DC: American Society for Microbiology.

Sambrook, J., Fritsch, E. F. \& Maniatis, T. (1989). Molecular Cloning: a Laboratory Manual 2nd edn. Cold Spring Harbor, NY : Cold Spring Harbor Laboratory.

Santero, E., Toukdarian, A., Humphrey, R. \& Kennedy, C. (1988). Identification and characterisation of two nitrogen fixation regulatory regions nif $A$ and $n f r X$ in Azotobacter vinelandii and Azotobacter chroococcum. Mol Microbiol 2, 303-314.

Son, H. S. \& Rhee, S. G. (1987). Cascade control of Escherichia coli glutamine synthetase. Purification and properties of $\mathrm{P}_{\mathrm{II}}$ protein and nucleotide sequence of its structural gene. $J$ Biol Chem 262, 8690-8695.

Thomas, G., Coutts, G. \& Merrick, M. (2000). The glnKamtB operon: a conserved gene pair in prokaryotes. Trends Genet 16, 11-14.

Toukdarian, A. \& Kennedy, C. (1986). Regulation of nitrogen metabolism in Azotobacter vinelandii: isolation of $n t r$ and $g \ln A$ genes and construction of $n t r$ mutants. EMBO J 5, 399-407.

Toukdarian, A., Saunders, G., Selman-Sosa, G., Santero, E., Woodley, P. \& Kennedy, C. (1990). Molecular analysis of the Azotobacter vinelandii $g \ln A$ gene encoding glutamine synthetase. J Bacteriol 172, 6529-6539.

Zheng, L., Cash, V. L., Flint, D. H. \& Dean, D. R. (1998). Assembly of iron-sulfur clusters. Identification of an iscSUA- $h s c B A-f d x$ gene cluster from Azotobacter vinelandii. J Biol Chem 273, 13264-13272.

Received 3 October 2000; revised 17 January 2001; accepted 22 January 2001. 